\section{Legado e relegado: notas sobre as contribuições de Bailey ao debate da questão racial no Brasil}

\author{
Paula Miranda-Ribeiro*
}

\begin{abstract}
BAILEY, Stanley R. Legacies of race: identities, attitudes, and politics in Brazil. Stanford: Stanford University Press, 2009, 294p.
\end{abstract}

Preciso confessar que, quando soube do lançamento de Legacies of race: identities, attitudes, and politics in Brazil, de Stanley Bailey, tive sentimentos contraditórios. Por um lado, a sensação foi de dèjá $v u$ - afinal, este é mais um livro de autor norte-americano que, ao analisar a questão racial no Brasil, dialoga com as relações raciais nos EUA. Por outro lado, fiquei curiosa e, ao mesmo tempo, animada pelo novo fôlego que o debate certamente ganharia no país. Reafirmo aqui o que escrevi anteriormente, em outra resenha: nunca é demais falar sobre raça e racismo porque estamos longe de eliminar as desigualdades raciais no país. Além disso, o momento não poderia ser mais oportuno, uma vez que, para além da discussão sobre ações afirmativas e políticas de cotas, que vez por outra ganha destaque na mídia, o lançamento do livro, em junho de 2009, coincidiu com o anúncio de que, pela primeira vez, uma novela das oito, da rede Globo, teria uma protagonista negra. ${ }^{1}$ Com isso, a questão racial estava novamente na ordem do dia.

Meu sentimento de dèjá vu desapareceu rapidamente. Composto por dez capítulos, o livro é muito bem escrito e organizado. A boa articulação entre os temas e a suave transição entre itens e capítulos tornam sua leitura fácil e agradável, apesar do forte peso dado à parte teórica, que permeia boa parte dos capítulos e, por sinal, constitui um dos seus pontos fortes. Analisando três pesquisas de opinião distintas, duas nacionais e uma no Estado do Rio de Janeiro - DataFolha (1995), Pesquisa Social Brasileira - PESB (2002) e Pesquisa sobre Atitudes Raciais no Rio de Janeiro (CEAP/DataUFF, 2000) -, o autor aborda as atitudes em relação a raça (capítulo 2), fronteiras entre as raças (capítulo 3), relação entre raça e cultura (capítulo 4), estratificação (capítulo 5), movimento negro (capítulo 6), ações afirmativas (capítulo 7), questão da classificação racial (capítulo 8) e classificação em apenas duas categorias (capítulo 9). Além destes, há um capítulo introdutório e outro de conclusão. Ao capturar o senso comum sobre a questão racial, o objetivo do livro é compreender de maneira mais ampla as atitudes raciais no Brasil contemporâneo e, por meio da comparação com os EUA, ajudar a entender as mudanças nas atitudes raciais que vêm ocorrendo neste último país.

O autor é, acima de tudo, cauteloso nas análises e, de certa forma, pouco precipitado nas conclusões, entre as quais se destacam três. Em primeiro lugar, os achados de Bailey apontam para o fato de que brancos e negros têm opiniões muito similares com relação a uma série de atitudes que envolvem mais diretamente a questão racial - por exemplo, os dados analisados sugerem que não é verdade o que diz o senso comum a respeito de os brancos brasileiros serem menos favoráveis às ações afirmativas do que os negros. Nesse sentido, brancos e negros são categorias mas não grupos, pois não possuem uma identidade que os una internamente e tampouco uma cultura comum e, ao mesmo tempo, suas opiniões não os distinguem uns dos outros.

Em segundo lugar, o autor afirma que há certa troca de papéis entre Brasil e EUA

\footnotetext{
* Professora associada do Departamento de Demografia e pesquisadora do Cedeplar, Universidade Federal de Minas Gerais (UFMG).

1 "Viver a Vida", de Manoel Carlos, estreou no dia 14 de setembro de 2009, com Thaís Araújo no papel de Helena.
} 
no que diz respeito à classificação racial. A partir do censo 2000, os EUA incluíram perguntas que permitiram levar em conta a miscigenação, ao passo que o Brasil, ao adotar políticas afirmativas que beneficiam os negros, força uma classificação dicotômica que nos aproxima da classificação branco/preto anteriormente adotada nos EUA.

Finalmente, Bailey sugere que as teorias utilizadas para explicar o caso brasileiro até o momento se mostram incapazes de lidar com a complexidade e as especificidades das relações raciais no país. Entretanto, com o movimento do Brasil no sentido de uma classificação monocromática, cada vez mais será possível utilizar aqui as teorias pensadas para dar conta do caso americano.

Pela complexidade da temática, este livro pode ser revisado a partir de vários enfoques, entre os quais estão os da sociologia, ciência política e comunicação. Minha formação, no entanto, só permite que eu me atreva pelos caminhos da demografia. Os comentários aqui estão organizados em torno dos legados do livro para os demógrafos (apesar do autor não ser demógrafo) e sobre o que fica relegado a um segundo plano, seja pelo autor, seja pelos próprios demógrafos.

Um dos grandes legados deste livro, para os demógrafos, é o alerta para as ambiguidades que estão por trás das categorias censitárias. $\mathrm{O}$ fato de um mesmo entrevistado, em um mesmo survey, migrar entre as categorias em função das diferentes formas de se capturar a classificação racial indica quão frágeis são estas categorias, algo com que os acadêmicos em geral e os demógrafos em particular não costumam se preocupar. No entanto, apesar da força das evidências, o autor não oferece alternativas às categorias que vêm sendo tradicionalmente utilizadas.

Outro legado é a utilização de outras fontes de dados que não os censos e as PNADs, permitindo investigar questões que vão muito além do escopo do quesito cor. Além disso, é extremamente positivo o uso de evidências qualitativas, sempre que disponíveis, no sentido de corroborar os resultados encontrados.

O autor ainda contrasta a visão do povo de uma maneira geral, dos acadêmicos e do Estado, por meio de suas ações. Colocar a questão racial na perspectiva das políticas públicas é uma importante contribuição ao debate.

Um ponto que merece ser ressaltado refere-se à discussão teórica que permeia todo o livro, sem a qual a compreensão das questões raciais brasileiras fica seriamente comprometida.

Apesar de Bailey dialogar com vários acadêmicos brasileiros ao longo do livro, a bibliografia traz poucas citações em português - das 328 referências, apenas 69 são em português, o que corresponde a meros $21 \%$ do total. Diante do volume e da importância da produção nacional sobre o tema, esta proporção parece muito reduzida.

Outro aspecto relegado a um segundo plano foi a grafia das palavras em português. Ao longo do livro, há vários erros que vão desde omissões e trocas de letras até uma enorme confusão entre português e espanhol, como a insistência em se referir ao IBGE como Instituto Brasileiro de Geografia e Estadísticas.

As possíveis diferenças regionais foram totalmente negligenciadas pelo autor. Ao analisar a pesquisa feita no Estado do Rio de Janeiro, Bailey não ressaltou as especificidades da realidade fluminense vis-à-vis o restante do país e, quando analisou as pesquisas nacionais, não buscou, em nenhum momento, apontar as diferenciais regionais.

Por fim, é de se lamentar que sexo e idade não tenham sido considerados na análise. As tentativas de incorporação destas variáveis são muito tímidas e não permitem comparações entre coortes ou evidências a respeito das conexões e superposições entre as questões raciais e de gênero. 